\title{
Die verhouding tussen dogmatiek en etiek in die teologie van J.A. Heyns
}

\author{
S.A. Strauss \\ Departement Dogmatologie \\ Universiteit van die Vrystaat \\ BLOEMFONTEIN \\ E-pos: sstrauss@iafrica.com
}

\begin{abstract}
The relationship between dogmatics and ethics in the theology of J.A. Heyns

The relationship between Amie van Wyk and Johan Heyns was characterized by congeniality. To honour Van Wyk, a central theme from the theology of Heyns is examined. The investigation covers both the aspects of Heyns' theoretical reflection on, as well as the practical application of the relationship between dogmatics and ethics. This investigation leads to the conclusion that Heyns' theology needs to be supplemented in this regard. A few examples of the possibilities that could extend Heyns' theology are suggested.
\end{abstract}

\section{Opsomming}

Die verhouding tussen dogmatiek en etiek in die teologie van J.A. Heyns Tussen Amie van Wyk en Johan Heyns was 'n geesgenootskaplike verhouding. Om Van Wyk te eer, word 'n sentrale tema uit die teologie van Heyns ondersoek. Die ondersoek dek Heyns se teoretiese nadenke oor, sowel as sy praktiese toepassing van die verhouding tussen dogmatiek en etiek. Dié ondersoek lei tot die gevolgtrekking dat Heyns se teologie op hierdie punt aangevul behoort te word. Enkele voorbeelde van moontlikhede waardeur Heyns se teologie uitgebrei kan word, word gebied.

\section{Inleiding tot ondersoek}

By die emeritaat van 'n hoog gewaardeerde kollega soos Amie van Wyk moet 'n gepaste bydrae gelewer word. Meer as een rede het aanleiding gegee tot die keuse van die tema van hierdie artikel. 
Die band van kongenialiteit tussen Van Wyk en Johan Heyns lê voor die hand. Heyns het mooi ideale vir Van Wyk gekoester en by geleentheid die hoop uitgespreek dat hy nog 'n omvattende etiek, wat "goedskiks 'n koninkryksetiek genoem kan word", gaan skrywe (Heyns, 1988:98 aangehaal op die titelblad van Van Wyk, 2001). Van Wyk het op sy beurt teen die einde van sy akademiese loopbaan vir Heyns uitgesonder as een van vyf teoloë van wie hy besonder veel geleer het en vir wie hy 'n bepaalde affiniteit ontwikkel het: "Heyns het my belangstelling gaande gehou vir filosofiese vrae in die teologie en die dringendheid van teologiese refleksie oor etiese vraagstukke" (Van Wyk, 2001: Voorwoord).

Die keuse van 'n tema om Van Wyk mee te vereer, mag dus maar uit die oeuvre van Heyns kom. Maar dit is op sigself natuurlik 'n te breë veld van ondersoek. Ek het op 'n stadium oorweeg om dan maar die grondlyne van Heyns se etiek te probeer ontleed en met Van Wyk s'n te vergelyk. Maar ook dit wou nie werk nie, want Van Wyk (1994 en 1995; ook 2001:214-237) het my daarin reeds voorgespring. Buitendien, Van Wyk se sesledige tipering van Heyns se etiek pas waarskynlik soos 'n handskoen op sy eie: Skriftuurlike, liefdes-, koninkryks- gehoorsaamheids-, situasie- en politieke etiek!

Die ondersoek moes dus nouer afgebaken word. Oor die verband tussen dogmatiek en etiek het sowel Heyns as Van Wyk uitdruklik nagedink. In die volgende paragrawe word dan eers gefokus op hierdie teoretiese besinning, en daarna op die praktiese uitwerking daarvan. Dit lei tot die gevolgtrekking dat die werk van Heyns op hierdie punt noodsaaklike aanvulling vereis. Ten slotte word ' $n$ enkele afleiding uit die ondersoek gemaak. Veral die praktiese waarde van die groter integrering van dogmatiek en etiek vir die huidige omstandighede sal aandag geniet.

\section{Teoretiese besinning}

Heyns se drieledige Teologiese Etiek (1982, 1986 \& 1989) bly tot op datum die volledigste en omvattendse etiese werk in Afrikaans. Na byna twee dekades verdien dit nog steeds deeglike bestudering. Heyns se teologie is per definisie 'n deur die tyd bepaalde antwoord op die openbaring van God (Heyns \& Jonker, 1974:137). Daarom sal nuwe omstandighede ook kritiek op sy ouer wordende antwoorde insluit (vgl. Van Niekerk, 1992). Dit doen egter geensins afbreuk aan die grondliggende waarde van sy prinsipiële denke, ook vir ons tyd, nie.

In die eerste deel van sy Teologiese Etiek (Heyns, 1982) word die voorvrae van die etiek sistematies aan die orde gestel. Reeds in die Voorwoord daarvan word ons tema terloops aangeraak. Heyns (1982:2) 
bevind dat daar in ons tyd 'n "merkwaardige grondverskuiwing" van die dogmatiese strydvrae na die etiese vraagstukke plaasgevind het. Nie soseer die regte leer nie, maar die korrekte lewe staan tans in die middelpunt van belangstelling. Verder aan in sy inleidende "Verkenning" beklemtoon Heyns (1982:31) die "onontbeerlike noodsaaklikheid" van etiese prediking vir ons tyd. Maar dan waarsku hy dat godsdiens en die etiese nie met mekaar verwar mag word, of dat die etiese die godsdienstige mag vervang nie. "Die godsdiens gaan aan die etiese vooraf." As hierdie grondstelling nie eerbiedig word nie, verloor die etiese nie alleen sy begronding nie, maar ontaard dit in 'n "moralistiese verdienstelikheid".

Self gee Heyns (1982:89 e.v.) 'n goeie voorbeeld van hoe hy meen dat godsdienstige (d.w.s. dogmatiese) waarhede die etiese moet begrond. Aan die hand van die trinitariese Godsleer werk hy uit hoe die Vader as die "skeppingsgrond", die Seun as die "herskeppingsgrond" en die Gees as die "voleindigingsgrond" van die etiese beskou moet word. Allerlei dogmatiese temas kom hier aan die orde, en die etiese konsekwensies voortvloeiend daaruit word getrek: skepping, verbond, versoening in en navolging van Christus, die inwoning en die vrug van die Gees en so meer. Hierdie innige verbinding tussen die dogmatiese en die etiese vind Heyns (1982:124) in so 'n mate in die Skrif self terug dat hy (met 'n koppelteken geskryf) van "die dogmaties-etiese dimensie van die Skrifopenbaring" kan praat. Terwyl die dogmatiek "die pisteologiesteoretiese" antwoord op die imperatief van die openbaring genoem kan word, is die etiek "die pisteologies-prakseologiese" antwoord daarop (Heyns, 1982:127). Woord én daad, leer én lewe hoort onlosmaaklik bymekaar.

Heyns (1982:131) se nadenke oor die verband tussen dogmatiek en etiek lei hom tot die gevolgtrekking dat "elke locus in die dogmatiek ... materiaal bied vir die wetenskap van die etiek". Hiervan gee hy dan 'n illustrasie deur, weliswaar baie kortliks, na die volgende loci te verwys: skepping, mens, sonde, verbond, Christus, en die Gees.

Bogemelde verspreide opmerkings loop uit op 'n afsonderlike en uitdruklike teoretiese besinning oor die verhouding tussen dogmatiek en etiek. Heyns (1982:138-148) begin deur te sê dat duidelikheid oor hierdie verhouding van meer as bloot akademiese belang is. Die verhouding van dié twee teologiese dissiplines sal bepaal of ook die dogmatiek tot 'n "kennisbron van die etiese" gereken behoort te word. Met kenmerkende deurdringende sistematiek deel Heyns die benadering van die verhouding tussen dogmatiek en etiek in die loop van die teologiegeskiedenis in drie kategorieë in. 
- Die eerste kategorie stel 'n "primaatsverhouding" voor: óf die etiek kry die primaat en die dogmatiek word daaraan ondergeskik gestel, óf, andersom, oorheers die dogmatiek die etiek. As voorbeelde van die eerste onderafdeling verwys hy na die sogenaamde etiese teologie, met sy slagspreuk dat die waarheid eties van aard is, asook die hedendaagse etiek van die revolusie, waar 'n etisering van die ganse teologie plaasvind. In sommige kringe van die tradisionele gereformeerde teologie (bv. W. Geesink), sê Heyns, word etiek volledig ondergeskik aan dogmatiek.

- Die tweede kategorie noem Heyns 'n "pariteitsverhouding" wat uitgaan van die eenheid en gelykheid van dogmatiek en etiek, met die gevolg dat die een in of saam met die ander behandel word. Verskillende voorbeelde kan genoem word: Augustinus, Thomas, Calvyn en Barth behandel almal etiese kwessies in hulle dogmatiek. Dit bring mee dat die etiek onselfstandig funksioneer, ondergeskik aan die dogmatiek.

- Die derde kategorie is 'n "identiteitsverhouding". Hieronder verwys Heyns (1982:142) na Schleiermacher, vir wie dogmatiek en etiek "twee parallellopende uitinge van die Christelike bewussyn" is.

Dit is onseker by watter een van die kategorieë Heyns homself skaar. Hy formuleer vervolgens drie oorwegings waardeur die juiste bepaling van die verhouding tussen dogmatiek en etiek gelei behoort te word: hulle mag nie geskei word nie; hulle moet onderskei word; dogmatiek moet aan etiek voorafgaan. Hieruit lei hy af (Heyns, 1982:144) dat ons moontlik van "'n dimensionele-rangorde-verhouding" ten opsigte van dogmatiek en etiek kan praat:

Geloof en lewe, dogmatiek en etiek, is sy en keersy, maar dan moet steeds met die sy begin word, want dit is die wortel waaruit die plant groei. Die plant is sonder die wortel volledig onmoontlik; die wortel sonder die plant onvolledig en onvrugbaar.

Nog anders gestel: "elke dogma het 'n etiese aspek, en die etiese het 'n dogmatiese aspek".

Heyns (1982:144 e.v.) sluit sy paragraaf oor "die intieme verhouding van dogmatiek en etiek" af deur te beklemtoon dat etiek, net soos dogmatiek noodwendig 'n konfessionele aard het. Omdat dogmatiek aan etiek voorafgaan, kan so 'n konfessionele aard maklik in byvoorbeeld die tradisionele Rooms-Katolieke of Lutherse etiek aangetoon word.

Dit is interessant om vir 'n oomblik daarop te let dat Van Wyk (1986:17 e.v.) hom enkele jare na Heyns met dieselfde tema op bykans dieselfde manier besighou. Hy bespreek weliswaar nie net die verhouding tussen 
etiek en dogmatiek nie, maar ook dié tussen etiek en ekklesiologie, missiologie, poimeniek, homiletiek en kategetiek ${ }^{1}$. Wanneer hy spesifiek op die verband tussen dogmatiek en etiek fokus, kom Van Wyk - ná sy kenmerkende talryke bronneverwysings - tot die gevolgtrekking dat die etiek "selfstandig - nie onafhanklik nie! - behandel" moet word. "Nóg die subordinering van die etiek aan die dogmatiek, nóg die subordinering van die dogmatiek aan die etiek is korrek, maar wel die koördinering van beide". Heyns sou hom waarskynlik met hierdie formulering kon vereenselwig. Aan die ander kant lyk dit tog asof hy, meer as Van Wyk, 'n bepaalde voorrang aan die dogmatiek toeken. Presies hoe Heyns hom die praktiese uitwerking van sy teoretiese insig voorgestel het, word in die volgende paragraaf nagegaan.

\section{Praktiese uitwerking}

In die hoofwerke van Heyns kom die praktiese uitwerking van die verhouding tussen dogmatiek en etiek slegs sporadies na vore. Laat ons dit chronologies nagaan.

\section{- Dogmatiek (1978)}

In Dogmatiek (Heyns, 1978) word geen bewuste poging aangewend om dogmatiek en etiek te integreer of selfs net te koördineer nie. In die inleidende hoofstukke oor die openbaring en die Heilige Skrif word glad nie na die etiek verwys nie. Weliswaar het Teologiese Etiek 1 (Heyns, 1982) later presies hierdie dogmatiese insigte benut vir die fundering van die etiek. Die hoofstuk oor die kennis van die etiese (Heyns, 1982:110173) maak ruimskoots daarvan gebruik. Op dieselfde manier word ook die Godsleer, by name die Triniteitsleer, aangewend vir wat Heyns (1982:89-109) die grond van die etiese noem. (Ons het dit reeds aangeraak in die vorige paragraaf).

Nog meer sulke parallelle sal tussen Heyns se dogmatiek en sy etiek uitgewys kan word. Om egter na Dogmatiek (Heyns, 1978) terug te keer - daarin tref 'n mens slegs enkele, byna terloopse verwysings na etiese temas aan. Ek stip hulle hier aan. In die hoofstukke oor die uitverkiesing en die skepping is daar letterlik niks hieroor nie. Uiteraard loop Heyns se bespreking van die mens uit op 'n breedvoerige behandeling van liefde, waaronder ook selfliefde. Sonder dat Heyns (1978:130 e.v.) die begrip etiek hier besig, is hy voluit presies daarmee besig! In die hoofstuk oor die voorsienigheid word nogal 'n stukkie "politieke etiek" behandel, sonder dat dié term gebruik word (Heyns, 1978:158-161). In sy hoofstuk

1 Vgl. Strauss (1988b:183) oor die interafhanklikheid van etiek met betrekking tot ander teologiese dissiplines. 
oor die sonde kom Heyns (1978:178 e.v.), klaarblyklik onbedoeld, weer by allerlei etiese sake uit as hy sonde in die verskillende verhoudinge waarin die mens staan, bespreek: arbeid, natuurbewaring, kuns, wetenskap, tegniek en politiek. In die hoofstuk oor die verbond staan niks oor etiek nie, maar in verband met die persoon en werk van Jesus Christus word uitdruklik verwys na "die etiese dimensie" in Christus se boodskap van die koninkryk van God (Heyns, 1978:278). Dit gaan dan oor die verband tussen gawe en opgawe, genade en verantwoordelikheid. Ook die hoofstukke oor die Heilige Gees en die genademiddele verwys nie na enige etiese aangeleentheid nie. In verband met die kerk (Heyns 1978:352 e.v.) kom allerlei temas aan die orde wat Heyns later in sy Teologiese Etiek (Heyns, 1986, 1989) breedvoerig uitgewerk het, byvoorbeeld die kerk as "eksemplariese gemeenskap" en die kerk se verhouding tot die wêreld as een van "kritiese solidariteit". Ten slotte vermeld die hoofstuk oor die voleinding die "religieus-etiese" aspek van sowel lewe as dood.

Heyns se Dogmatiek (1978) lewer dus nie 'n goeie voorbeeld van hoe sy teoretiese insig in die verhouding tussen dogmatiek en etiek prakties uitgewerk behoort te word nie. Waarskynlik was dit ook nie 'n uitdruklike doelstelling met die skryf daarvan nie. Nogtans is daar telkens sprake van ' $n$ byna onwillekeurige verbinding tussen die dogmatiese en die etiese, vanweë die aard van die verhouding tussen hulle as sodanig.

\section{- Teologiese Etiek I (1982)}

Dieselfde gevolgtrekking kan gemaak word as 'n mens Heyns se drie dele Teologiese Etiek met die oog op ons tema fynkam. Selde word daar uitdruklik na die verhouding tussen dogmatiek en etiek verwys, maar dikwels speel juis hierdie verhouding 'n deurslaggewende rol. Om weer na Teologiese Etiek 1 (1982) terug te keer - behalwe die verbindingslyne wat ons reeds tussen Heyns se dogmatiek en etiek uitgewys het, kan daar ook nog op die volgende gewys word.

Op die eerste oog af lyk dit asof Heyns se fundering van die etiese 'n sterk filosofiese inslag het. Hy skryf agtereenvolgens oor die grond van, kennis van, norme vir, subjek van en horison van die etiese. Uiteraard skroom Heyns nie om van filosofiese kategorieë in sy teologiese etiek gebruik te maak nie. Dit hang saam met sy siening van die verhouding tussen teologiese en (Christelik) filosofiese etiek (Heyns, 1982:51 e.v.). Nader beskou, is sy skynbaar filosofiese denke egter deurdrenk van dogmatiese insigte. Wat hy reeds in sy Dogmatiek (1978) in verband met die leer oor God, die openbaring en die Skrif vasgestel het, word hier voluit in diens van die etiek aangewend. Veral onder die opskrif "Voorsienigheidswoord" (een van die ses "Woordgestaltes" wat hy onder- 
skei), maak Heyns (1982:112 e.v.) waardevolle opmerkings oor 'n Bybelse geskiedenis- en werklikheidsbeskouing. God regeer so deur sy voorsienigheidswoord dat daar nie net 'n "skeppingsorde" nie, maar ook 'n "skeppingsdinamiek" aan ons geopenbaar word. Hierdie grondinsigte bied aan hom vrymoedigheid om in verband met die aard van etiese norme (Heyns, 1982:180 e.v.) naas universeel geldende geopenbaarde norme ook rekening te hou met gepositiveerde sowel as kontingente (of: situatiewe) norme. Onder die opskrif "Horison van die etiese" skryf Heyns (1982:212 e.v.) selfs 'n hele hoofstuk oor die teologiese dimensie van die fenomeen "situasie". Daarin maak hy die belangrike uitspraak dat die situasie opgeneem is in God se historiese realiseringsproses wat Hy volgens sy raadsplan voltrek (1982:213). Hieraan voeg hy dan in 'n voetnoot (1982:220) toe: "Ons waardering van die situasie en beskouing oor veral die kontingente norme, is 'n poging tot herwaardering van die skeppingsopenbaring". ${ }^{2}$

Dieselfde intieme verbinding tussen dogmatiek en etiek word ook sigbaar wanneer Heyns (1982:192 e.v.) sy hoofstuk oor "Die subjek van die etiese" skryf. Basies kom hierin niks anders as sy hoofstuk oor die mens in sy Dogmatiek (1978) aan die orde nie. In hierdie opsig rus die mure van sy etiek dus stewig op die fondamente van sy dogmatiek.

Die laaste hoofstuk in Teologie Etiek 1 handel oor Heyns se weergawe van individuele etiek. Dit is interessant dat hy, naas die temas wat gewoonlik in die persoonlike etiek aandag geniet, met opset begin met die etiese lewe as 'n "lewe van roeping en gehoorsaamheid" (Heyns, 1982:363 e.v.). Sonder dat hy dit in hierdie paragaaf uitdruklik vermeld, moes sy dogmatiese insig in die koninkryk - waaraan hy weer nie 'n aparte hoofstuk in sy Dogmatiek (1978) wy nie - in hierdie formulering 'n belangrike rol gespeel het. In dieselfde hoofstuk beskryf hy onder andere ook die etiese lewe as 'n "lewe van lyding" (Heyns, 1982:493 e.v.). Daarin gryp hy terug op wat hy reeds in verband met die lyding van Christus in sy Dogmatiek (1978) gesê het. Terloops, hierdie bladsye oor lyding is een van die aangrypendste voorbeelde van Heyns se vermoë om pastoraal-bewoë oor etiese temas te skryf. Heel aan die einde van Teologiese Etiek 1 word, in verband met lyding, ook aan die dood aandag gegee. Dan sê Heyns (1982:503) dat dit hier nie om daardie aspekte gaan wat hy reeds in sy Dogmatiek (1978) behandel het nie. Die "etiese vraag ten opsigte van die dood" is vir hom eenvoudig: "Wat is die gestalte wat aan die lewe gegee word in die lig van die dood ...? Of andersom: wat is die gestalte wat aan die houding t.o.v. die dood gegee

2 Jonker (1994:22) sien ook raak dat Heyns aan die algemene openbaring " $n$ baie meer positiewe betekenis toeskryf as wat ons in die gereformeerde dogmatiek gewoond is". Maar daarmee is natuurlik nog nie bewys dat dit noodwendig verkeerd is nie! 
word in die lig van die ewige lewe ...?" Vir Heyns se besef het etiek dus met praktiese vrae van lewe en dood te make.

\section{- Teologiese Etiek 2/1 en 2/2 (1986, 1989)}

Heyns werk sy sosiale etiek breedvoerig uit in die tweede en derde dele van sy Teologiese Etiek. In die formele gedeelte van Teologiese Etiek 2/1 (1986) gaan hy weer skynbaar sterk filosofies te werk wanneer hy agtereenvolgens die eienskappe, bestemming, ontaarding en herstel van die samelewingsverbande bespreek. Nogtans gee hy weer daaraan 'n dogmatiese onderbou, deur 'n hele hoofstuk aan die koninkryk van God te wy (Heyns, 1986:38-67). Dáárin vind alle samelewingsverbande volgens hom hulle bestemming. Ook in die gedeelte oor "die norme vir die sosiaal-etiese lewe in die samelewingsverbande" (Heyns, 1986:98 e.v.) val hy weer terug op allerlei dogmatiese begrippe soos gehoorsaamheid, geregtigheid, versoening, hoop en so meer. Dieselfde kan van sy ontleding van die huwelik, die gesin, en kultuur (waaronder arbeid, tegniek, wetenskap, kuns, kommunikasiemedia en ontspanning) gekonstateer word. Nêrens egter, sover ek kon vasstel, verwys hy in soveel woorde na wat hy in die eerste deel Etiek (1982): "die intieme verhouding tussen dogmatiek en etiek" genoem het nie. Klaarblyklik was dit nie sy bedoeling om in sy Etiek hierdie verhouding eksplisiet in die praktyk uit te werk nie.

Dieselfde gevolgtrekking kan ook na aanleiding van Teologiese Etiek 2/2 (Heyns, 1989) gemaak word. Daarin behandel Heyns agtereenvolgens die samelewingsverbande van die volk, die staat en die kerk. Op haas elke bladsy sou die leser die verband tussen sy dogmatiek en etiek kon aantoon. So lig hy byvoorbeeld in verband met die oorsprong van die staat ook die menslike aandeel daaraan uit. Sy gevolgtrekking is dan (Heyns, 1989:119):

Deur sy Voorsieningheidswoord lei God die mens om in gehoorsaamheid aan die appèl van die Voorsieningheidswoord en finaal genormeer deur die Skrifgeworde woord, die nodige samelewingsverbande te konkretiseer.

In so 'n volsin hoor 'n mens die grondlyne van Heyns se dogmatiek resoneer in ten minste die loci oor God, openbaring, Skrif en die mens. Dié een voorbeeld sou vermenigvuldig kon word. Weereens verwys hy in hierdie boekdeel egter nêrens uitdruklik na die verhouding tussen dogmatiek en etiek nie.

\section{- Inleiding tot die Dogmatiek (1992)}

In sy laaste groot werk, Inleiding tot die Dogmatiek aan die hand van die Nederlandse Geloofsbelydenis (1992), gee Heyns weer uitdruklik aan 
ons tema aandag. Reeds in sy "Verantwoording" (Heyns, 1992:2) verduidelik hy waarom hy naas 'n tetiese uiteensetting van die dogmatiese stof ook telkens gaan verwys na eksegetiese, historiese, etiese, kerugmatiese en apologetiese aspekte. In verband met die etiese sê hy dat die dogmatiek "nie net 'n suiwer teoretiese aangeleentheid" is nie. "Dit het ook 'n ander kant, waar dit gaan om die mens se optrede ten opsigte van homself en teenoor ander mense." Dieselfde gedagtelyn word gevolg om te verduidelik dat dogmatiek in verskillende "ruimtes" (geloof, konfessie, ekumene, praktyk en kultuur) beoefen word (Heyns, 1989:34-37). Met die "praktiese ruimte" wil hy "die onlosmaaklike eenheid van dogmatiek en etiek" uitdruk. Hy sê:

Dit is inderdaad so dat dogmatiek en etiek in 'n verhouding van sy en keersy staan. Die ander kant van dogmatiek is etiek, en die ander kant van etiek is dogmatiek. Al is dit dan ook so dat 'n mens met die dogmatiek-kant moet begin. Wie dogmaties nagedink het oor God en sy liefde vir die mens, kom vanself uit by die mens en sy liefde vir die naaste. Wie suiwer van hart is, kan nie vuil van hande wees nie (vgl. Ps. 24:4).

Heyns werk hierdie plan dan prakties uit deur aan die einde van die bespreking van die artikels van die Nederlandse Geloofsbelydenis ook 'n etiese aspek toe te voeg. Ongelukkig gebeur dit nie by elke artikel nie. Dit laat die indruk dat hy sy voorneme nie volledig sistematies gestand gedoen het nie, maar lukraak hier en daar aktuele kwessies betrek.

Nogtans gee hy 'n aantal goeie voorbeelde van hoe die etiese konsekwensies uit dogmatiese waarhede getrek kan word. Ek kan hier na die volgende verwys:

- By art. 2 (die middele waardeur ons God ken) die respek vir natuur en kultuur, asook die Woord as enigste norm (Heyns, 1992:73 e.v.).

- By art. 13 (voorsienigheid) die vryheid en verantwoordelikheid van die mens, teenoor determinisme en fatalisme (p. 166 e.v.).

- By art. 14 (skepping van die mens en sondeval) menseregte, die heerlikheid van die mens, teenoor verheerliking, en die hele mens as beeld van God - ook liggaamlik (p. 186).

- By art. 15 (erfsonde) die weerspreking van elke humanistiese selfverheffing (p. 196).

- By art. 18 (die menswording van Christus) wat ons van depressie en lewensmoegheid bewaar (p. 230).

- By art. 21 (versoening) die diepste geheim van ons menswees om, soos Christus, vir God en medemens te leef en te sterf (p. 258). 
- By art. 25 (die wet in Christus vervul) die hele kwessie van (geoorloofde teenoor nie-geoorloofde) situasie-etiek (p. 297).

- By art. 36 (die owerheid) die beoordeling van etiese vraagstukke soos burgerlike ongehoorsaamheid en oorlog (p. 401).

Aan die ander kant wek dit egter verbasing dat Heyns byvoorbeeld by die volgende, myns insiens belangrike temas, geen etiese aspekte aandui nie:

- By art. 5 (die gesag van die Skrif)

- By art. 8 (die Drieënheid)

- By art. 19 (die twee nature van Christus)

- By art. 26 (Christus ons voorspraak)

- By art. 33-35 (sakramente: doop en nagmaal)

Van Wyk (2001:216) maak êrens die opmerking dat wie Heyns se etiek goed wil verstaan, nie net sy etiese werke kan raadpleeg nie. "In die dogmatiese werke sit volop etiek soos wat daar in die etiese werke volop dogmatiek sit." Dit is korrek. Maar wanneer Van Wyk daaraan toevoeg dat Heyns in sy Inleiding tot die Dogmatiek (1992) "baanbrekerswerk gedoen (het) deur die aandag te vestig op die etiese konsekwensies van dogmatiese uitsprake", lyk dit my na 'n al te vleiende beoordeling. Heyns se bedoeling om só 'n dogmatiek - met - etiek te skryf, is wel baanbrekerswerk. Maar sy praktiese uitvoering van hierdie projek is te onafgerond om veel daarmee uit te rig.

\section{Noodsaaklike aanvulling}

Die gevolgtrekking uit ons ondersoek tot dusver is duidelik. Heyns se teologie bied 'n aanvaarbare teoretiese besinning oor die verhouding tussen dogmatiek en etiek. Die praktiese uitwerking daarvan egter bied, hoewel bruikbare, tog nog onafgeronde voorbeelde van hoe dié tema sistematies uitgewerk behoort te word. Om Heyns se werk in hierdie opsig te probeer aanvul, is noodsaaklik vir die vrugbare beoefening van teologiese etiek in ons tyd. Met enkele voorbeelde wil ek graag hierdie paar stellings toelig.

Wanneer die verhouding tussen dogmatiek en etiek vasgestel word, is dit 'n vraag of dit nie eerder die dogma, in onderskeiding van die dogmatiek (as wetenskaplike dissipline), is wat die verbinding tussen die twee vakgebiede vorm nie. Heyns het hom ongelukkig nie diepgaande met die dogma as sodanig (as leer van die kerk) in sy Inleiding tot die Dogmatiek besig gehou nie. Mag ek hier in beskeidenheid verwys na 'n volledige 
ondersoek na riglyne vir die etiek in die gereformeerde belydenisskrifte? En mag ek die resultate van die destydse ondersoek (Strauss, 1988a:142-144) as 'n voorbeeld hier volledig weergee? Dit geskied met die hoop dat dit ook vir ander navorsers, soos vir my, van waarde kan wees.

Ons Belydenisskrifte handhaaf ten opsigte van etiese kwessies deurgaans 'n uitgesproke teologiese uitgangspunt. Die grondstelling waarmee die NGB (art. 1) begin, word konsekwent volgehou: God is die oorsprong van alles wat bestaan, dit wil sê ook van alles wat eties goed is. Alles waarmee ons in die etiek te doen kry, moet dus ook in die lig van sy ewige raad en voorsienigheid beskou word selfs so iets soos rykdom en armoede (HK, So. 9 en 10). Uiteraard beteken dit geen fatalisme nie. Maar dié uitgangspunt bewaar ons ten ene male daarvan dat ons totaal verbouereerd en oorweldig sal word deur die enorme etiese problematiek van ons tyd. God is nog in beheer.

Uit dié teologiese uitgangspunt vloei daar 'n normatiewe benadering van die etiek voort. Dit is veral die NGB (art. 2-7) wat uitvoerig die reformatoriese sola Sciptura, ook in etiese sake, bely. Niks anders as die Woord van God mag in die kerk die gewetens van mense bind nie (art. 29, 32). Net die Bybel, maar dan ook die hele Bybel (art. 25 ), het die laaste woord in alle sake wat die leer en die lewe van die Christene raak. Natuurlik staan hierdie Skrifgeloof nie los van die Christus-geloof nie. Veral die HK herinner ons altyd weer aan Christus. Hy is immers die hoogste Leraar van sy kerk (So. 12). En omdat Christus self die wet van God geëer het, moet ons dit ook doen. Die maatstaf vir die dankbaarheid en die goeie werke wat God van ons eis, bly steeds sy wet (So. 33, Vr. 91); dit is, konkreet, die tien gebooie (So. 34 e.v.). Nie dat die tien gebooie los van Christus staan nie. Inteendeel, die Christelike lewenswandel word juis deur Christus self moontlik gemaak ( $v g l$. die 'nut' van sy dood en sy opstanding. So. 16 e.v.). Daarom moet die wet ook met die oog op die vervulling in en deur Hom heilshistories in die lig van die hele Skrif in Ou en Nuwe Testament, verklaar word (vgl. bv. So. 38 oor die Sabbat).

Die Belydenisskrifte werk nie met 'n modern, optimistiese mensbeskouing nie. Konsekwent word 'n Skriftuurlike antropologie daarop nagehou. Dit beteken dat die mens oorspronklik goed en as die beeld van God geskep is. Maar sedert die sondeval het die hele menslike geslag só verdorwe geraak dat hy al sy voortreflike gawes verloor het (NGB, art. 14 e.v.). Hy is glad nie meer in staat om iets goeds te doen nie (HK, So. 3). Selfs die ou klein bietjie lig van die natuur wat na die sonde in hom oorgebly het, kan hy nie eers in burgerlike sake reg gebruik nie (DL III/IV, 4)! Dit is somber woorde, maar dit is waar woorde. 'n Etiek wat nie konsekwent met hierdie antropologiese riglyn rekening hou nie, kan wel allerhande moralis- 
tiese wetenswaardighede kwytraak. Maar dit sal nie meer konfessioneel-gereformeerde etiek genoem kan word nie.

Wat die mens uit homself hoegenaamd nie kan doen nie, kan die almagtige God wel doen! Hy is immers die troue Verbondsgod wat nie die werk van sy hande laat vaar nie. Wanneer die Drie Formuliere oor die verlossing van die mens handel, doen hulle dit vanuit die verbond as raamwerk. Dit is veral die DL (vgl. bv. II,8) wat hierdie raamwerk eksplisiet noem. Maar ook wanneer dit nie uitdruklik gesê word nie, is die gedagte implisiet aanwesig. Die leer van die verbond beklemtoon 'n aantal teologiese grondinsigte wat ook vir die etiek van groot betekenis is. Dit bring eerstens mee dat die volstrek teologiese uitgangspunt (vgl. hierbo) ook in die soteriologie gehandhaaf moet word. Nie net die regverdiging nie, maar ook die heiliging moet ten diepste na die ewige besluit van God, die uitverkiesing, herlei word (DL I, 7). Dáár lê die oorsaak, die 'fontein' van alle heil ook van etiese deugde soos gehoorsaamheid en heiligheid (DL I, 9). Die verbondsleer bring tweedens mee dat die menslike verantwoordelikheid - so belangrik vir die etiek - konsekwent gehandhaaf moet word. Die verbond omvat nie net beloftes nie, maar ook eise en vermanings (DL II, 5; III/IV, 11 e.v.). Daarmee kom die wet, naas die evangelie, andermaal vir die etiek in die visier. Van die wedergebore mens kan met reg verwag word dat hy sy etiese verantwoordelikheid moet nakom.

Vanuit die verbond loop daar 'n logiese lyn na die verlossingsleer. Met die oog op die etiek moet dit benadruk word dat ons Belydenisskrifte 'n omvattende soteriologie verkondig. Daarmee word bedoel dat dit die verlossing van die mens in sy totaliteit, vanaf verkiesing en regverdiging tot by heiliging en verheerliking, beskryf. Die Belydenisskrifte gebruik nie die latere gangbare dogmatiese terminologie in die heilsorde nie. Die hele vernuwing van die mens uit genade word telkens vanuit 'n ander gesigspunt beskryf as 'wedergeboorte', 'bekering', e.s.m. Wat hier beklemtoon moet word, is dat daar geen skeiding tussen regverdiging en heiliging kan wees nie. Herhaaldelik word gesê dat dit 'onmoontlik' is dat iemand wat 'n ware geloof ontvang het, nie ook werke van dankbaarheid sal voortbring nie (NGB, art. 24; HK, So. 24; DL I, 13; V, 12 e.v.). Dié toedrag van sake is daaraan te danke dat Christus nie halwe werk doen nie. Hy vergewe én Hy vernuwe ons, Hy skenk regverdiging én heiliging (vgl. HK, So. 32). Dit word deurgaans ook pneumatologies uitgewerk. Die Heilige Gees is immers ons Heiligmaker deur sy inwoning in ons harte (NGB, art. 9). Deur die Heilige Gees maak Christus ons bereidwillig om vir Hom te lewe (HK, So. 1). Dit is dieselfde Gees wat die 'wedergeboorte', in die sin van lewensvernuwing, skenk (DL III/IV, 11 e.v.). Uit hierdie gegewens blyk nog eens die streng teologiese uitgangspunt van die gereformeerde geloof: sola gratia! Terselfdertyd word die menslike verantwoordelikheid gehandhaaf. 
Dit is die (deur die Gees weergebore) mens wat goeie werke moet doen. Hy word selfs daartoe aangespoor deur die motivering dat hy van sy geloof uit sy werke verseker kan word (HK, So. 32; DL V, 10).

Vanuit die pneumatologie moet daar aan die genademiddels gedink word. Telkens beklemtoon die Drie Formuliere die rol van die regte kerklike bediening ter ondersteuning van die Christelike lewenswandel. Ons dink hier aan die etiese dimensie van die gebruik van die sakramente, doop sowel as nagmaal (NGB, art. 34 e.v.; HK, So. 26-28, 30; DL III/IV, 17). Dan is daar ook die raakvlak tussen die kerklike tug en die regte lewenswandel (NGB, art. 29; HK, So. 31; $\mathrm{DL}$ III/IV, 17). Laastens moet daar in hierdie verband daaraan herinner word dat ook die oefening in die geloof, die sogenaamde askese, in die gereformeerde etiek ' $n$ rol behoort te speel (vgl. veral die gedeelte van die HK oor die gebed, So. 45 e.v.). Kortom, die Christelike etiek kan nie los van die ekklesiologie en die diakoniologie beoefen word nie. Ook hierdie riglyn moet in ons tyd in gedagte gehou word.

Ons Belydenisskrifte dink nie net aan die 'geestelike' lewe nie. Daar is ook die breë terrein van die burgerlike lewe waar etiese norme gehoorsaam moet word. Soos reeds gesê, kan hierdie norme nie uit die 'natuurlike lig' afgelei word nie (vgl. DL III/IV, 4). Daarom spreek die Skrif ook in hierdie sake die beslissende woord. Hoe die gereformeerdes die Skrif in dié verband gehanteer het, blyk veral uit die HK se verklaring van die tweede tafel van die wet (So. 39 e.v.). Maar reeds die NGB het duidelike riglyne in verband met die taak van die burgerlike owerheid en die gehoorsaamheid daaraan neergelê (NGB, art. 36). Ook vir die etiek van die daaglikse arbeid is daar prinsipiële aanduidings in die HK (So. 42, 49). Waarlik, die Belydenisskrifte voed geen ongesonde Doperse myding van die wêreld nie.

Die reaksie teen die Wederdopers se theologia gloriae blyk ook duidelik op die punt van die afwysing van die perfeksionisme. Dit geskied vanuit, wat ons kan noem, 'n eskatologiese realisme. Volmaaktheid kan nie reeds in hierdie lewe bereik word nie (vgl. HK, So. 44, 52; DL I, 16; V 1 e.v.). Dié oortuiging lei egter nie tot 'n kompromie-mentaliteit nie. Die streng eis van God se gebooie moet steeds onvervals verkondig word. Juis die wet prikkel ons om te bid dat die Heilige Gees ons altyd 'meer en meer' mag vernuwe - al sal die volmaaktheid eers na hierdie lewe bereik word (HK, So. 44).

Ten slotte moet die riglyn van die motief agter elke etiese handeling van die gelowige aangedui word. Dit is die gereformeerde beginsel van soli Deo gloria. In ons Belydenisskrifte word die gedagte uitdruklik vermeld in die HK (So. $32,47,52)$ en in die slot van die DL $(\mathrm{V}, 15)$. Daarmee is die sirkel van ons gedagtegang voltooi. Die 
eerste riglyn vir die etiek wat ons genoem het, was die teologiese uitgangspunt. Dit word ook by die ander riglyne gehandhaaf. En hier aan die einde kom die gesindheid van die strewe na die eer van God weer aan die orde. Per slot van rekening gaan dit in die gereformeerde belydenis, en daarom ook in die gereformeerde etiek, ten diepste om die 'uit en deur en tot' Hom (Rom. 11:36).

Op 'n soortgelyke manier, meen ek, sal dit ook moontlik wees om by elke locus in die dogmatiek die etiese konsekwensies daarvan uit te werk.

\section{Afleiding uit ondersoek}

In sy afskeidsrede kort voor sy heengaan kom Heyns (1994:6 e.v.) vir oulaas op die tema van ons ondersoek terug. Daarin omskryf hy die Bybel as "'n verhaal-met-dogma en 'n verhaal-met-moraal". Dié verhaal van God se omgang met sy wêreld, roep ons "tot geloof en tot handelinge, tot leer en lewe ...". Dit gaan daarin "om die vulling van die geloof en om die gestaltegewing van die handelinge". Indien dit waar is, sal dit dan nie moontlik wees om in een asem by elke geloofswaarheid ook die gehoorsame handeling wat daarby pas, te bespreek nie?

Vanweë die fragmentasie van die wetenskap, ook die teologie, is dit uiters noodsaaklik om in ons tyd die dogmatiese en die etiese nouer op mekaar te betrek en met mekaar te verbind. Heyns se bedoeling in hierdie verband wag op ' $n$ jonger geslag wat dit in die praktyk sal uitwerk. Dit sal verhoed dat dogmatiek al meer 'n vak word wat vrae beantwoord wat niemand meer stel nie. En dit sal voorkom dat die etiek sy stof al meer uit (gesekulariseerde) menswetenskappe put.

\section{Bibliografie}

HEYNS, J.A. \& JONKER, W.D. 1974. Op weg met die teologie. Pretoria : NGKB.

HEYNS, J.A. 1978. Dogmatiek. Pretoria : NGKB.

HEYNS, J.A. 1982. Teologiese Etiek I. Pretoria : NGKB.

HEYNS, J.A. 1986. Teologiese Etiek 2/1. Pretoria : NGKB.

HEYNS, J.A. 1988. Resensie van J.H. van Wyk, "Gesindheid en gestalte". Skrif en Kerk, 9(1):97-98.

HEYNS, J.A. 1989. Teologiese Etiek 2/2. Pretoria : NGKB.

HEYNS, J.A. 1992. Inleiding tot die dogmatiek aan die hand van die Nederlandse Geloofsbelydenis. Pretoria : NGKB.

HEYNS, J.A. 1994. Die koninkryk van God - grondplan van die Bybel. Skrif en Kerk, 15(1):1-12.

JONKER, W.D. 1994. In gesprek met Johan Heyns. Skrif en Kerk, 15(1):13-26.

STRAUSS, S.A. 1988a. Riglyne vir die etiek in die Drie Formuliere van Eenheid. (In De Bruyn, P.J., red. Waar die paaie saamwoon. Bundel wetenskaplike opstelle aangebied aan prof. P.W. Buys. Potchefstroom : Potchefstroomse Teologiese Publikasies. p. 131-145.)

STRAUSS, S.A. 1988b. Ampsbediening en etiese beslissings. (In Rossouw, P.J., red. Gereformeerde ampsbediening. Pretoria : NGKB. p. 183-195.) 
VAN NIEKERK, A.C.J. 1992. Kan J.A. Heyns se sosiale etiek ons teologies toerus vir die toekoms? Skrif en Kerk, 13(1):221-233.

VAN WYK, J.H. 1986. Gesindheid en gestalte. Pretoria : NGKB.

VAN WYK, J.H. 1994. Analogiese eksistensie. Aantekeninge by die etiek van J.A. Heyns I. Skrif en Kerk, 15(1):141-155.

VAN WYK, J.H. 1995. Analogiese eksistensie. Aantekeninge by die etiek van J.A. Heyns II. Skrif en Kerk, 16(1):159-170.

VAN WYK, J.H. 2001. Etiek en eksistensie in koninkryksperspektief. Potchefstroom : Potchefstroomse Teologiese Publikasies.

\section{Kernbegrippe:}

dogmatiek van J.A. Heyns

etiek van J.A. Heyns

verhouding tussen dogmatiek en etiek

\section{Key concepts:}

dogmatics of J.A. Heyns

ethics of J.A. Heyns

relationship between dogmatics and ethics 